\title{
Relationships of Afroablepharus Greer, 1974 skinks from the Gulf of Guinea islands based on mitochondrial and nuclear DNA: Patterns of colonization and comments on taxonomy
}

\author{
José Jesus $^{\mathrm{a}, *}$, D. James Harris ${ }^{\mathrm{b}}$, António Brehm ${ }^{\mathrm{a}}$ \\ ${ }^{a}$ University of Madeira, Department of Biology, Campus da Penteada, 9000-390 Funchal, Portugal \\ ${ }^{\mathrm{b}}$ Centro de Investigação em Biodiversidade e Recursos Genéticos (CIBIOIUP), Campus Agrário de Vairão, 4485-661 Vairão, Portugal
}

Received 5 February 2007; revised 17 July 2007; accepted 18 August 2007

Available online 31 August 2007

\begin{abstract}
Partial sequences of three mitochondrial DNA genes, 12S rDNA, 16S rDNA and cytochrome $b$, and one nuclear gene, $c-m o s$, were used to assess the phylogenetic relationships of species belonging to the genus Afroablepharus from the volcanic islands of the Gulf of Guinea (West Africa) and neighboring continental Africa. Additionally, partial sequences of cytochrome $b$ were used to compare levels of sequence divergence within populations. The three forms from São Tomé, Príncipe and Annobon (one per island) are genetically distinct, with high levels of divergence, supporting the recognition of a distinct species in each island. Populations within each island contain very low levels of genetic diversity. These three forms form a monophyletic group suggesting a single initial colonization followed by radiation to the other islands, possibly from São Tomé to Príncipe and Annobon. This is contrary to what was found in other reptiles from these islands such as Mabuya (sensu lato) and Hemidactylus, which colonized the islands multiple times. Assuming a molecular clock for cytochrome $b$ of about $2 \%$ divergence per million years (usually applied to Sauria), the lineage on Annobon island exceeds the age of the island, thus casting further doubt on this widely used divergence estimate.

Partial sequences of $c$-mos showed no variation within islands. Five to seven sites were variable among islands, which is a high value further supporting the treatment of each island form as a distinct species.
\end{abstract}

(c) 2007 Elsevier Inc. All rights reserved.

Keywords: 12S rDNA; 16S rDNA; Cytochrome b; C-mos; Panaspis; Afroablepharus; Gulf of Guinea; São Tomé; Príncipe; Annobon

\section{Introduction}

The forests of West Africa, including the islands of the Gulf of Guinea (Fig. 1) form one of the world's biodiversity hotspots (Myers et al., 2000; Measey et al., 2007). These islands are on a straight axis and part (oceanic sector) of the Cameroon Volcanic Line, which is a flaw or hotline (Meyers et al., 1998) in the African tectonic plate, about $1500 \mathrm{~km}$ long (Simkin and Siebert, 1994; Burke, 2001). Bioko is the largest and closest island to the main-

\footnotetext{
* Corresponding author. Fax: +351 291705399.

E-mail address: jesus@uma.pt (J. Jesus).
}

land, about $32 \mathrm{~km}$ from Cameroon and formerly connected to the mainland. The other three islands are smaller and were never connected to the mainland or to each other.

Príncipe is about $220 \mathrm{~km}$ southwest from Bioko and $146 \mathrm{~km}$ northeast of São Tomé. Annobon is situated about $180 \mathrm{~km}$ southwest from São Tomé. Príncipe $\left(128 \mathrm{~km}^{2}\right)$ is at least $31 \mathrm{Myr}$ old, and São Tomé $\left(836 \mathrm{~km}^{2}\right)$ is at least $13 \mathrm{Myr}$ old (Lee et al., 1994). The youngest and smallest of the Gulf of Guinea islands $\left(17 \mathrm{~km}^{2}\right)$ is Annobon with an estimated age of 4.9 Myr old (Lee et al., 1994). This isolation has promoted species divergence, and the islands currently harbor several endemic species including amphibians (Measey et al., 2007), Hemidactylus geckos (Jesus et al., 2003, 2005a), Lygodactylus geckos (Jesus et al., 


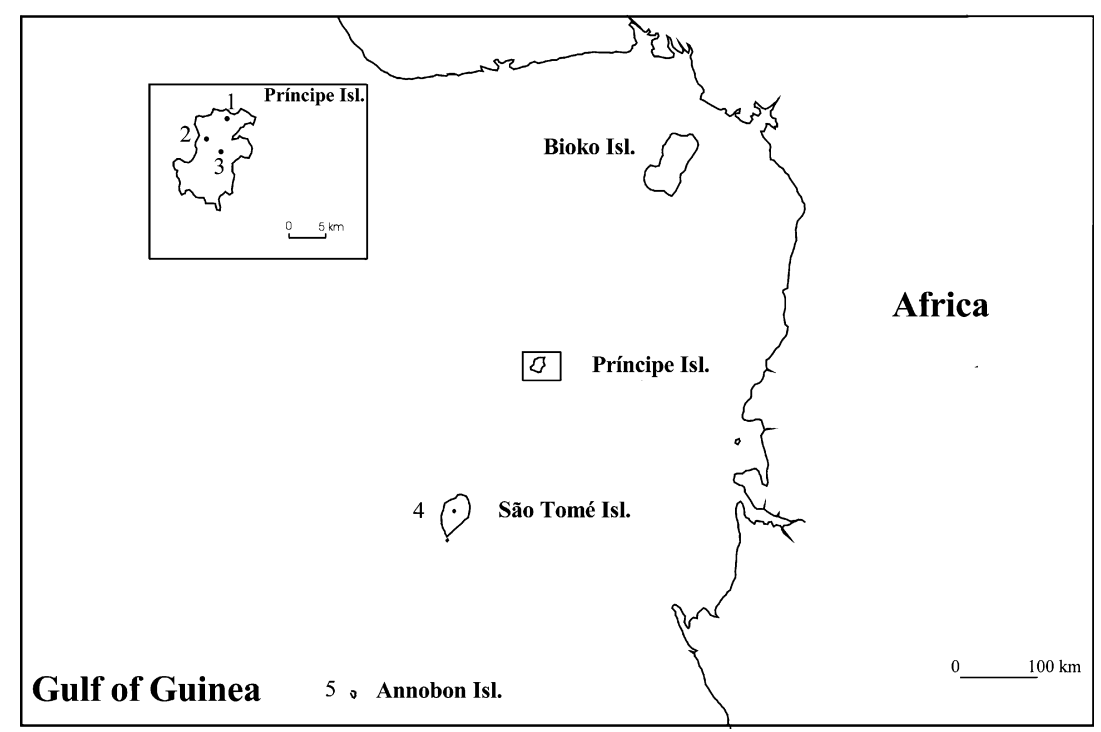

Fig. 1. Map showing sampling localities of Afroablepharus spp. from Gulf of Guinea islands sampled in this study. Numbers are as follows: 1. PríncipePonta do Sol, 2. Príncipe-Montalegre, 3. Príncipe-Terreiro Velho, 4. São Tomé-Vale do Contador, 5. Annobon.

2006) Mabuya (sensu lato) skinks (Jesus et al., 2003, 2005b, $2005 \mathrm{c}$ ), and skinks currently assigned to the genus Afroablepharus.

The genus Panaspis has undergone substantial systematic rearrangement since its creation by Cope in 1868 (see for example, Boulenger, 1887; Smith, 1937; Mittleman, 1952; Fuhn, 1969, 1972; Perret, 1973, 1975; Welch, 1982). Based on morphological characters, Greer, 1974 suggested a new genus, Afroablepharus for the species with an ablepharine eye and the contact between the frontal scale and just one subocular scale. The other species, without ablepharine eye, including $P$. cabindae, were included in the genus Panaspis.

Molecular data (partial sequences of $12 \mathrm{~S}$ rDNA and $16 \mathrm{~S}$ rDNA) was recently used by Schmitz et al., 2005 in a revision of the genus Panaspis sensu lato. These authors found considerable genetic differentiation between the different subgenera, and suggested elevation of four former subgenera (Panaspis, Afroablepharus, Leptosiaphos and Lacertaspis) to generic rank. The results of Schmitz et al., 2005 suggest that Panaspis africana from Príncipe should be renamed Afroablepharus africanus, despite the absence of an ablepharine eye and the contact between the frontal scale and subocular made between the frontal and just one subocular. The closest extant relative of $A$. africanus, known so far, is A. wahlbergi (Schmitz et al., 2005), a sub-Saharan species found in West Africa.

Fuhn (1972) judged Panaspis skinks from Annobon sufficiently different to be considered a distinct subspecies, Panaspis africana annobonensis. His study revealed that this subspecies was distinct from the nominal subspecies in the following morphological characters: higher number of subdigital lamellae of the 4th toe of hind limbs, higher number of subdigital lamellae of the 4th toe of fore limbs, relatively longer limbs, the broader first loreal, darker coloration, presence of a darker subocular band well marked, and the presence of a spotted gular region. Based on Fuhn's study, Perret, 1973 and Welch (1982) considered the subspecies $P$. africana annobonensis Fuhn, 1972 so distinct that they suggested raising the subspecies to full species rank, $P$. annobonensis.

It has been shown that skinks of the genus Mabuya colonized these islands independently from the mainland (Jesus et al., 2005c), unlike the Cape Verde islands where all extant Mabuya resulted from a single colonization (Bre$\mathrm{hm}$ et al., 2001). Also, the island endemic geckos of the genus Hemidactylus do not form a monophyletic group, suggesting multiple independent colonization events of the islands, contrary to the geckos of the genus Lygodactylus, which apparently colonized these islands only once (Jesus et al., 2006). All of these studies showed extensive variation between forms from the different islands, indicating extensive cryptic variation.

Our main objectives were to study the relationships of the Afroablepharus spp. from São Tomé, Príncipe and Annobon islands, to assess the colonization patterns of these islands, and to examine levels of variation among the island lineages. This should help to identify cryptic variation, and to contribute towards understanding how these islands were colonized, and whether a comparable phylogeographic pattern exists across different taxa.

\section{Materials and methods}

\subsection{Sampling and molecular methods}

The geographic locations and the numbers of specimens used in this study are given in Table 1 and Fig. 1. All individuals of São Tomé, Príncipe and Annobon islands used in this study are deposited in the reptile collection of the University of Madeira. Total genomic DNA was extracted from small pieces of tail by phenol-chloroform standard protocols (Sambrook et al., 1989). PCR primers used in 
Table 1

Details of material and sequences used in the present study; origin of sequences and samples, specimens code, and GenBank Accession Nos.

\begin{tabular}{l} 
Species \\
\hline Afroablepharus africanus \\
Afroablepharus africanus \\
Afroablepharus africanus \\
Afroablepharus africanus \\
Afroablepharus africanus \\
Afroablepharus africanus \\
Afroablepharus africanus \\
Afroablepharus africanus \\
Afroablepharus africanus \\
Afroablepharus africanus \\
Afroablepharus africanus \\
Afroablepharus africanus \\
Afroablepharus africanus \\
Afroablepharus africanus \\
Afroablepharus africanus \\
Afroablepharus africanus \\
Afroablepharus sp.
\end{tabular}

Afroablepharus sp.

Afroablepharus annobonensis Afroablepharus annobonensis Afroablepharus annobonensis Afroablepharus annobonensis Afroablepharus annobonensis Afroablepharus annobonensis Afroablepharus annobonensis Afroablepharus annobonensis Afroablepharus annobonensis Afroablepharus annobonensis Afroablepharus annobonensis Afroablepharus annobonensis Afroablepharus annobonensis Afroablepharus annobonensis Afroablepharus annobonensis Afroablepharus africanus

Afroablepharus wahlbergi

Panaspis togoensis

Panaspis breviceps I

Panaspis breviceps II

Lacertaspis gemmiventris

Lacertaspis gemmiventris I

Lacertaspis gemmiventris II

Lacertaspis gemmiventris III

Lacertaspis gemmiventris IV

Lacertaspis gemmiventris $\mathrm{V}$

Lacertaspis gemmiventris VI

Lacertaspis lepesmei

Lacertaspis chriswildi

Lacertaspis rhodei I

Lacertaspis rhodei II

Locality Specimen code

Specimen code Accession Nos.

$12 \mathrm{~S} \quad 16 \mathrm{~S}$

Cytochrome $b \quad C$-mos

Terreiro Velho, Príncipe, Gulf of Guinea

Terreiro Velho, Príncipe, Gulf of Guinea

Terreiro Velho, Príncipe, Gulf of Guinea

Terreiro Velho, Príncipe, Gulf of Guinea

Terreiro Velho, Príncipe, Gulf of Guinea

Terreiro Velho, Príncipe, Gulf of Guinea

Terreiro Velho, Príncipe, Gulf of Guinea

Ponta do Sol, Príncipe, Gulf of Guinea

Ponta do Sol, Príncipe, Gulf of Guinea

Ponta do Sol, Príncipe, Gulf of Guinea

Ponta do Sol, Príncipe, Gulf of Guinea

Ponta do Sol, Príncipe, Gulf of Guinea

Ponta do Sol, Príncipe, Gulf of Guinea

Montalegre, Príncipe, Gulf of Guinea

Montalegre, Príncipe, Gulf of Guinea

Montalegre, Príncipe, Gulf of Guinea

Vale do Contador, São Tomé, Gulf of

Guinea

Vale do Contador, São Tomé, Gulf of

Guinea

Annobon, Gulf of Guinea

Annobon, Gulf of Guinea

Annobon, Gulf of Guinea

Annobon, Gulf of Guinea

Annobon, Gulf of Guinea

Annobon, Gulf of Guinea

Annobon, Gulf of Guinea

Annobon, Gulf of Guinea

Annobon, Gulf of Guinea

Annobon, Gulf of Guinea

Annobon, Gulf of Guinea

Annobon, Gulf of Guinea

Annobon, Gulf of Guinea

Annobon, Gulf of Guinea

Annobon, Gulf of Guinea

Príncipe, Gulf of Guinea

Pilgrims Rest, South Africa

Benakuma, West of Wum, Cameroon

Mt. Kupe, Cameroon

Mt. Nlonako, Cameroon

Ekona Lulu, Mt. Cameroon, Cameroon

Bioko Id.: vic Moka Malabo, Equatorial Guinea

Bioko Id.: vic Moka Malabo, Equatorial

Guinea

Bioko Id.: vic Moka Malabo, Equatorial Guinea

Bioko Id.: vic Moka Malabo, Equatorial Guinea

Bioko Id.: vic Moka Malabo, Equatorial Guinea

Bioko Id.: vic Moka Malabo, Equatorial

Guinea

Bamboutos, "House of the Fulbe",

Cameroon

Tchabal Mbabo, Cameroon

Mt. Nlonako, Cameroon

Nzobi, Banyang-Mbo, Mt. Cameroon,

Cameroon

$\begin{array}{lllll}\text { Pt1 } & \text { EU164427 } & \text { EU164462 } & \text { EU164505 } & \\ \text { Pt2 } & \text { EU164428 } & \text { EU164463 } & \text { EU164506 } & \\ \text { Pt3 } & \text { EU164429 } & \text { EU164464 } & \text { EU164507 } & \\ \text { Pt4 } & \text { EU164430 } & \text { EU164465 } & \text { EU164508 } & \\ \text { Pt5 } & \text { EU164431 } & \text { EU164466 } & \text { EU164509 } & \text { EU164500 } \\ \text { Pt6 } & \text { EU164432 } & \text { EU164467 } & \text { EU164510 } & \\ \text { Pt7 } & \text { EU164433 } & \text { EU164468 } & \text { EU164511 } & \\ \text { Pp1 } & \text { EU164434 } & \text { EU164469 } & \text { EU164512 } & \\ \text { Pp2 } & \text { EU164435 } & \text { EU164470 } & \text { EU164513 } & \\ \text { Pp3 } & \text { EU164436 } & \text { EU164471 } & \text { EU164514 } & \\ \text { Pp4 } & \text { EU164437 } & \text { EU164472 } & \text { EU164515 } & \\ \text { Pp5 } & \text { EU164438 } & \text { EU164473 } & \text { EU164516 } & \\ \text { Pp6 } & \text { EU164439 } & \text { EU164474 } & \text { EU164517 } & \text { EU164499 } \\ \text { Pm1 } & \text { EU164440 } & \text { EU164475 } & \text { EU164518 } & \text { EU164501 } \\ \text { Pm2 } & \text { EU164441 } & \text { EU164476 } & \text { EU164519 } & \\ \text { Pm3 } & \text { EU164442 } & \text { EU164477 } & \text { EU164520 } & \\ \text { Sv1 } & \text { EU164443 } & \text { EU164478 } & \text { EU164521 } & \text { EU164502 } \\ & & & & \\ \text { Sv2 } & \text { EU164444 } & \text { EU164479 } & \text { EU164522 } & \text { EU164503 }\end{array}$

An1 EU164445 EU164480 EU164523

An2 EU164446 EU164481 EU164524

An3 $\quad$ EU164447 EU164482 EU164525

An4 EU164448 EU164483 EU164526

An5 $\quad$ EU164449 EU164484 EU164527

An6 EU164450 EU164485 EU164528

An7 EU164451 EU164486

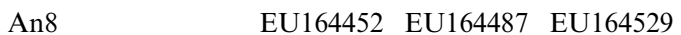

An9 EU164453 EU164488 EU164530

An10 EU164454 EU164489

An11 EU164455 EU164490 EU164531

An12 EU164456 EU164491 EU164532

An13 EU164457 EU164492 EU164533

An14 EU164458 EU164493 EU164534

An15 EU164459 EU164494 EU164535

$\mathrm{BMNH}$,

uncatalogued

ZFMK $77818 \quad$ AY308327 AY308178

MNHM 2001.0699 AY308441 AY308290

Voucher not AY308439 AY308287

collected

ZFMK $75380 \quad$ AY308440 AY308288

MNHN 2002.0024 AY308383 AY308233

CAS $207861 \quad$ AY308376 AY308227

CAS 207860

AY308377 AY308228

CAS 207858

AY308378 AY308229

CAS 207854

AY308379 AY308230

CAS 207857

AY308381 AY308231

CAS 207855

AY308382 AY308232

MNHN 2004.0061 AY308384 AY308234

ZFMK 75735

AY308375 AY308226

ZFMK 75382

AY308386 AY308236

MNHN 2002.0797 AY308387 AY308237
EU164498

EU164497 
Table 1 (continued)

\begin{tabular}{|c|c|c|c|c|c|c|}
\hline \multirow[t]{2}{*}{ Species } & \multirow[t]{2}{*}{ Locality } & \multirow[t]{2}{*}{ Specimen code } & \multicolumn{4}{|c|}{ Accession Nos. } \\
\hline & & & $12 \mathrm{~S}$ & $16 \mathrm{~S}$ & Cytochrome $b$ & $C-m o s$ \\
\hline Lacertaspis rhodei III & $\begin{array}{l}\text { Limbo, Banyang-Mbo, Mt. Cameroon, } \\
\text { Cameroon }\end{array}$ & MNHN 2002.0796 & AY308388 & AY308238 & & \\
\hline Lacertaspis reichenowi & Mt. Nlonako, Cameroon & ZFMK 68965 & AY308385 & AY308235 & & \\
\hline Leptosiaphos sp. I & Mt. Nlonako, Cameroon & ZFMK 69551 & AY308401 & AY308251 & & \\
\hline Leptosiaphos sp. II & Mt. Nlonako, Cameroon & ZFMK 68291 & AY308402 & AY308252 & & \\
\hline Leptosiaphos sp. III & Mt. Nlonako, Cameroon & ZFMK 69554 & AY308403 & AY308253 & & \\
\hline Leptosiaphos sp. IV & Mt. Nlonako, Cameroon & $\begin{array}{l}\text { Voucher not } \\
\text { collected }\end{array}$ & AY308408 & AY308254 & & \\
\hline Leptosiaphos sp. V & Mt. Nlonako, Cameroon & ZFMK 75381 & AY308407 & AY308255 & & \\
\hline Leptosiaphos sp. VI & $\begin{array}{l}\text { Bioko Id.: vic Moka Malabo, Equatorial } \\
\text { Guinea }\end{array}$ & CAS 207864 & AY308405 & AY308256 & & \\
\hline Leptosiaphos sp. VII & $\begin{array}{l}\text { Bioko Id.: vic Moka Malabo, Equatorial } \\
\text { Guinea }\end{array}$ & CAS207865 & AY308406 & AY308257 & & \\
\hline Leptosiaphos amieti & Mt. Nlonako, Cameroon & ZFMK 69530 & AY308392 & AY308242 & & \\
\hline Leptosiaphos vigintiserierum I & Mt. Nlonako, Cameroon & ZFMK 69429 & AY308410 & AY308258 & & EU164504 \\
\hline Leptosiaphos vigintiserierum II & Mt. Cameroon, Cameroon & MNHN 2004.0062 & AY308409 & AY308259 & & \\
\hline Leptosiaphos kilimensis I & Usambara: Kwamkoro, Tanzania & ZFMK 77815 & AY308399 & AY308249 & & \\
\hline Leptosiaphos kilimensis II & Usambara: Amani, Tanzania & ZFMK 77816 & AY308398 & AY308248 & & \\
\hline Leptosiaphos kilimensis III & Ke, Chuka, Kenya & ZFMK 77817 & AY308393 & AY308243 & & \\
\hline Leptosiaphos koutoui & Meiganga, Cameroon & MNHN 2001.0697 & AY308400 & AY308250 & & \\
\hline Leptosiaphos graueri I & Bwindi Impenetrable NP, Uganda & CAS 201705 & AY308396 & AY308244 & & \\
\hline Leptosiaphos graueri II & $\begin{array}{l}\text { Kabale-Kayonza, Bwindi Impenetrable NP, } \\
\text { Uganda }\end{array}$ & CAS 201776 & AY308394 & AY308245 & & \\
\hline $\begin{array}{l}\text { Leptosiaphos graueri } \\
\text { quinquedigitata }\end{array}$ & Gakarara, Rwanda & ZFMK 55877 & AY308395 & AY308246 & & \\
\hline Leiolopisma telfarii & & & AF280122 & AY 151450 & & \\
\hline Chalcides chalcides & & & AJ416936 & AJ416935 & & \\
\hline Mabuya maculilabris & Rolas islet, são Tomé, Gulf of Guinea & 562 & EU164460 & EU164496 & AY997748 & \\
\hline Mabuya vaillanti & & & & & & AF335088 \\
\hline Mabuya fogoensis & & & & & & AF335082 \\
\hline Feylinia polylepis & Terreiro Velho, Principe, Gulf of Guinea & 579 & EU164461 & EU164495 & EU164536 & \\
\hline
\end{tabular}

Species names are according to suggestions and results reported by Schmitz et al. (2005). Taxon designation for Annobon, Afroablepharus annobonensis, is according to suggestions made by Perret (1973). Codes refer to voucher specimens. Except for Afroablepharus spp. from Annobon, São Tomé and Príncipe islands, and Mabuya maculilabris, Feylinia polylepis and Leptosiaphos vigintiserierum (only for C-mos), the source of information was GenBank. Data about localities and voucher names of the sequences from GenBank were provided by Andreas Schmitz (pers. comm.).

both amplification and sequencing were $12 \mathrm{Sa}$ and $12 \mathrm{Sb}$ (Kocher et al., 1989), 16SL and 16SH (Simon et al., 1990), cytB1 and CB3H (Palumbi et al., 1991), and G73 and G74 for a fragment of the nuclear gene, c-mos (Saint et al., 1998). Two other primers were used for sequencing the cytochrome $b$ gene: cytochrome $b 2$ from Kocher et al. (1989) and P1 (in this study, 5'-TGA GGA CAA ATA TCA TTY TGR GG-3'). The PCR cycling procedure was as follows. For $12 \mathrm{~S}$ rDNA, an initial denaturation step: 4 min at $94{ }^{\circ} \mathrm{C} ; 35$ cycles: denaturation $30 \mathrm{~s}$ at $94^{\circ} \mathrm{C}$, primer annealing for $30 \mathrm{~s}$ at $50{ }^{\circ} \mathrm{C}$; extension for $30 \mathrm{~s}$ at $72{ }^{\circ} \mathrm{C}$; and a final step of $5 \mathrm{~min}$ at $72{ }^{\circ} \mathrm{C}$. For $16 \mathrm{~S}$ rDNA, an initial denaturation step: $5 \mathrm{~min}$ at $85^{\circ} \mathrm{C} ; 35$ cycles: denaturation $35 \mathrm{~s}$ at $94{ }^{\circ} \mathrm{C}$, primer annealing for $3 \mathrm{~s}$ at $50^{\circ} \mathrm{C}$; extension for $1 \mathrm{~min}$ at $72^{\circ} \mathrm{C}$; and a final step of $5 \mathrm{~min}$ at $72^{\circ} \mathrm{C}$. For cytochrome $b$, an initial denaturation step: 5 min at $85^{\circ} \mathrm{C} ; 35$ cycles: denaturation $40 \mathrm{~s}$ at $94^{\circ} \mathrm{C}$, primer annealing for $50 \mathrm{~s}$ at $50{ }^{\circ} \mathrm{C}$; extension for $2 \mathrm{~min}$ $72{ }^{\circ} \mathrm{C}$; and a final step of $5 \mathrm{~min}$ at $72^{\circ} \mathrm{C}$. For $c$-mos, an initial denaturation step: $3 \mathrm{~min}$ at $94{ }^{\circ} \mathrm{C} ; 40$ cycles: denaturation $25 \mathrm{~s}$ at $94{ }^{\circ} \mathrm{C}$, primer annealing for $55 \mathrm{~s}$ at $50{ }^{\circ} \mathrm{C}$; extension for $40 \mathrm{~s}$ at $70^{\circ} \mathrm{C}$; and a final step of $3 \mathrm{~min}$ at $72{ }^{\circ} \mathrm{C}$. PCR fragments were sequenced in a ABI 310 sequencer (Applied Biosystem DNA Sequencing Apparatus).

DNA sequences were aligned using Clustal W (Thompson et al., 1994). Two data sets were considered, one with combined aligned 12S rDNA and 16S rDNA sequences of about $366 \mathrm{bp}$ and $417 \mathrm{bp}$, respectively, and another with combined aligned 12S rDNA, 16S rDNA and cytochrome $b$ of about $366 \mathrm{bp}, 417 \mathrm{bp}$ and $640 \mathrm{bp}$, respectively. The first dataset included more outgroups because more were available in GenBank for these two genes. The second included fewer outgroups for the combined gene sequences. Cytochrome $b$ revealed no indels. These two datasets were used to estimate the phylogenetic relationships among taxa. Only cytochrome $b$ (about $640 \mathrm{bp}$ long) was used to estimate the genetic distances and divergence times of samples from São Tomé, Príncipe and Annobon. Because phylogenetic reconstruction is based on positional homologies, the regions that could not be unambiguously aligned due to extensive length variations were excluded from further 
analysis (50 bp from 16S rDNA). The alignment is available on request from the corresponding author. We sequenced the 12S rDNA and 16S rDNA fragments in 33 Afroablepharus, and for cytochrome $b$ we sequenced 31 Afroablepharus samples from the Gulf of Guinea islands (see Table 1). For 12S rDNA and 16S rDNA we compared this, for phylogenetic analysis, to 35 overlapping partial sequences of $12 \mathrm{~S}$ rDNA and 16S rDNA of mainland Panaspis (sensu lato; Schmitz et al., 2005), that were fully overlapping with our 783 bp sequences. We also included in this analysis the partial sequences of these two genes from several outgroups: one individual of Mabuya maculilabris from São Tomé (Rolas islets, voucher \#562, Jesus et al., 2005b), one Chalcides chalcides (GenBank Accession No., AJ416936, for 12S rDNA, and AJ416935 for 16S rDNA) and one Leiolopisma telfairii (GenBank Accession No., AF280122, for $12 \mathrm{~S}$ rDNA, and AY151450 for $16 \mathrm{~S}$ rDNA) (Table 1). For the combined dataset of $12 \mathrm{~S}$ rDNA, 16S rDNA and cytochrome $b$ we used sequences from 31 individuals and, for phylogenetic analysis, we added two outgroups, Mabuya maculilabris and Feylinia polylepis (see Table 1). For $c$-mos we sequenced 31 individuals (2 from São Tomé, 14 from Annobon and 14 from Príncipe) resulting in a fragment of $331 \mathrm{bp}$. No intra-island variation was found, so we just used for further phylogenetic analysis 2 sequences from São Tomé (Sv1 and Sv2), 3 from Príncipe (Pp6, Pt5 and Pm1), and 2 from Annobon (An14 and An15). C-mos data were included as an independent nuclear marker. We also analysed $c$-mos sequences from Leptosiaphos vigitiserierum, Mabuya vaillanti (\#AF335088) and one Mabuya fogoensis (\#AF335082) as outgroups.

\subsection{Data analysis}

True evolutionary relationships may be obscured in DNA sequence data sets if sites have become saturated by multiple substitutions (Swofford et al., 1996). To test for saturation, observed pairwise proportions of transitions and transversions in the separate $12 \mathrm{~S}$ rDNA, $16 \mathrm{~S}$ rDNA and cytochrome $b$ were plotted against sequence divergence and calculated using DAMBE version 4.2.13 (Xia and Xie, 2001).

Differences in substitution rates between gene regions can potentially produce conflicting signals if one gene is saturated. Thus, before proceeding with the analysis, a partition-homogeneity test was applied to data (Farris et al., 1994) implemented in PAUP* $4.0 b 10$ (Swofford, 2002) to evaluate whether the two or three gene regions contained significantly different phylogenetic signals. This test indicated no significant incongruence between regions ( $p=0.68$ (matrix of 2 genes), $p=0.96$ (matrix containing the three genes)), so they were combined in the phylogenetic analysis.

The data were imported to PAUP* $4.0 \mathrm{~b} 10$ (Swofford, 2002) and to MEGA version 3.1 (Kumar et al., 2004) for phylogenetic analysis. For the phylogenetic analysis we used maximum likelihood (ML) and Bayesian inference. We followed the approach outlined by Huelsenbeck and Crandall (1997) to test 56 alternative models of evolution, employing PAUP* 4.0b10 and Modeltest 3.7 (Posada and Crandall, 1998). Once a model of evolution was chosen according to Akaike information criterion following Posada and Buckley (2004), it was used to estimate a tree using ML criteria (Felsenstein, 1985). An heuristic search with tree bisection reconnection (TBR) and 10 replicates of random addition of taxa was performed to estimate a tree. Steepest descent option was not in effect, and the MULPARS option was used. The relative robustness of each dichotomy was established by bootstrap analysis. Non-parametric bootstrap support for nodes was estimated using the "fast" option with 100 heuristic bootstrap replicates implemented in PAUP* 4.0b10. The Bayesian analysis was implemented using MrBayes v3.1.2.(Huelsenbeck and Ronquist, 2001), which calculates Bayesian posterior probabilities using a Metropolis-coupled, Markov chain Monte Carlo (MC-MCMC) analysis. Bayesian analysis was conducted with random starting trees, four MCMC chains (one cold, three heated), run $0.5 \times 106$ generations, and sampled every 100 generations using a General-Time-Reversible model of evolution with a gamma model of among-site rate variation. Two additional analyses were performed with different numbers of generations, $5 \times 106$ and $1 \times 107$, giving the same results. In all searches stationarity of the Markov Chain was determined as the point when sampled negative log-likelihood values plotted against the number of generations reached a stable mean equilibrium value; "burn-in" data sampled from generations preceding this point were discarded. The burn-in value was 500 for combined $12 \mathrm{~S}$ rDNA and $16 \mathrm{~S}$ rDNA dataset and 1000 for combined 12S rDNA, 16S rDNA and cytochrome $b$ dataset. Convergence between runs (as measured by effective sample size, ESS) and posterior probabilities of the estimates were determined using the software program Tracer (Rambaut and Drummond, 2005). According to Ho et al. (2005), the effective population size is influenced not only by the number of samples that are drawn from the MCMC but also by the degree of autocorrelation among samples. The preliminary analysis revealed that the burn-in was sufficient. This was confirmed by a posterior analysis of the MCMC samples with program Tracer. All data collected at stationarity were used to estimate posterior nodal probabilities and a summary of phylogeny. These posterior probabilities of each clade were used as a support measure. This analysis was repeated for the two datasets, the combined $12 \mathrm{~S}$ rDNA and $16 \mathrm{~S}$ rDNA, and the combined 12S rDNA, 16S rDNA and cytochrome $b$. Because of the very low levels of sequence variation in $c$-mos, a MP analysis was performed for this dataset. The maximum parsimony searches were performed in Mega version 3.1 using close-neighbor interchange with 1000 bootstrap replicates. The starting trees for closeneighbor interchange were selected by random addition with 1000 replicates and a search level of 3 . 


\section{Results}

Plots of observed pairwise divergences of haplotypes for transitions and transversions in the separate $12 \mathrm{~S}$ rDNA, $16 \mathrm{~S}$ rDNA and cytochrome $b$ against total sequence divergence revealed negligible saturation (data not shown), so our analyses included all sites.

The combined $12 \mathrm{~S}$ and 16S rDNA gene fragments gave a total segment of $783 \mathrm{bp}$ with 245 variable sites of which 197 were parsimony informative. The most appropriate model for the combined data was the GTR model (Rodríguez et al., 1990), with a discrete approximation to a gamma-distributed rate-heterogeneity model $(\alpha=0.5807)$, and an estimate of invariable sites $(I=0.5284)$. An heuristic search incorporating this model found one tree of $-\ln$ 4617.63. Bayesian analysis, considering the GTR $+\mathrm{I}+\mathrm{G}$ model, produced a very similar estimate of relationship as the ML analysis. The main differences were in relationships among haplotypes from the same island. The combined 12S rDNA, 16S rDNA and cytochrome $b$ gene fragments gave a total segment of $1416 \mathrm{bp}$ with 419 variable sites of which 282 were parsimony informative. The most appropriate model for the combined data was the GTR model (Rodríguez et al., 1990), with a discrete approximation to a gamma-distributed rate-heterogeneity model $(\alpha=0.5452)$, and an estimate of invariable sites $(I=0.4002)$. An heuristic search incorporating this model found one tree of $-\ln 4749.63$. Bayesian analysis, considering the GTR $+\mathrm{I}+\mathrm{G}$ model, produced a similar estimate of relationship, again with differences restricted to short nodes connecting haplotypes from the same island.

A similar pattern of relationships was found either using the $12 \mathrm{~S}$ rDNA + $16 \mathrm{~S}$ rDNA dataset, or using all mitochondrial data. The use of more characters did not improve the support for relationships. The node that separates the Príncipe from São Tomé samples is better supported in the first dataset (bootstrap value $=97$ ), than the second dataset (bootstrap value $=59$ ). Usually when we increase the length of sequences, the bootstrap values increase. This is not the case, and probably this is due to different outgroups being used in the two datasets; in this situation bootstraps (i.e. support values) cannot be directly compared.

In all analyses, haplotypes from the three islands formed a clade with $100 \%$ support. Major clades, particularly those identified by Schmitz et al., 2005 are also well supported with $99-100 \%$ support (Figs. 2 and 3).

Also well supported is the relationship between the group of forms from São Tomé, Príncipe and Annobon, and the sister-taxon $A$. wahlbergi, as well as the relationship between this group (Afroablepharus spp.) and the its sistertaxon Panaspis spp. (Fig. 2).

Levels of sequence divergence between congeneric reptile species is known to average approximately $12 \%$ for cytochrome $b$ (Harris, 2002). Sequence divergence for cytochrome $b$ between populations from Annobon and Príncipe is approximately $21 \%$, between Annobon and São Tomé $22 \%$, and between Príncipe and São Tomé divergence is approximately $23 \%$ (Tables 2 and 3). The minimum value obtained was between an individual of Príncipe and an individual of Annobon (0.203). Intra-island cytochrome $b$ divergences are substantially lower than inter-island divergences (Table 3).

The $c$-mos sequences revealed no variation within populations. However between Annobon and Príncipe the sequences differed in five sites, between Annobon and São Tomé in 7, and between São Tomé and Príncipe in six sites. These values were much higher than those observed between Mabuya vaillanti (\#AF335088) and Mabuya fogoensis \#AF335082 (only 3), distinct species from the Cape Verde islands. These results are in agreement with mtDNA data and support the hypothesis that the high divergences found in the cytochrome $b$ data are not an artefact, but represent overall high divergences between island forms. These values are also higher than those found in Lygodactylus from these islands (Jesus et al., 2006). The MP tree shows that a clear differentiation exists between the three island forms of Gulf of Guinea (Fig. 4). No heterozygotes were found, and only three haplotypes, one per island, were found in these islands. The three forms were also clearly differentiated from the other species included in the analysis. Both nuclear and mitochondrial DNA sequences gave the same results with the recognition of a clade formed by Príncipe and São Tomé, although with high divergence between samples of these two islands. In both analyses the Príncipe + São Tomé and Annobon appear as sister clades (Figs. 2-4).

\section{Discussion}

\subsection{Patterns of colonization in the islands of Gulf of Guinea}

Analysis of $12 \mathrm{~S}$ rDNA, 16S rDNA and cytochrome $b$ sequences produced robust estimates of relationships for the populations from the three islands. From our analyses we can state: (i) the results suggest monophyly of Gulf of Guinea species, and thus indicate a single initial colonization event followed by radiation to the other islands; (ii) the ancestor of the three forms dispersed to the islands from Western Africa (perhaps within the current range of Afroablepharus wahlbergi). The closest related mainland Afroablepharus (A. wahlbergi) is distributed in eastern and western Africa from South Africa to Democratic Republic of Congo.

When a single colonization event occurs in an archipelago, the simplest model of inter-island colonization is that of stepping stone colonization. However sometimes the topology of the tree is not congruent with this simple model. According to Emerson (2002) there are some methods for inference of sequence of colonization. One method uses tree topology and geography under the premise that an island will be colonized by neighboring island rather than a more distant one. The other method infers the direction of colonization using information from tree topology and branch length. This method is based on the assumption 


\section{Pt1}

$\mathrm{Pp} 2$

Pp 3

Pp4

Pt2

Pt5

Pml

m2

m3

6

7

Afroablepharus africanus

$\left.{ }_{100}\right|_{\text {Sv2 }} ^{\text {Sv1 } \quad \text { São Tomé }}$

94 An1

An1

An5

An5

An4

An6

An6
An 7

100 An8

An8

94

An13

11

An12

An14

An15

- Afioablepharus wahlbergi.

Annobon

88 - Panaspis cf togoensis

100 [ Panaspis breviceps I

Lanaspis breviceps II

- Lacertaspis gemmiventris

100 Lacertaspis gemmive ntris I

9) Lacertasp iss gemmiventris III

$73{ }^{9}$ Lacertaspis gemmiventris IV

- Lace rtaspis gemmi ventris V 100 Tace rtaspis gemmiventris VI

$\infty$ Lacertasp is chris wildi

Lacertasp is chris wildi

4 Lacertos pis rohdei

-Lacertaspis reichenowi

100 Leptosiaphos sp. I

94 Leptosiaphos amieti

Leptosiaphos sp. II

Leptosiaphos sp. III

10 Leptosiaphos sp. IV

- Leptosiaphos vigintiserierum I

Leptosiaphos vigintiserierum II

100 ho Leptosiaphos sp. V

100 Le Leptosiaphos sp. VI

100

Leptosiaphos sp. VI

or Leptosiaphos kilimensis I

Leptosiaphos kilimensis II

${ }_{100}$ Leptosiaphos kilimensis II

Leptosiaphos koutoui

100 -Leptosiaphos graueri II

${ }_{100}$ Leptosiaphos graueri I

Leptosiaphos graueri quinquedigitata

Leiolopisma telfairii

0.5 substitutions $/ \mathrm{site}$

Fig. 2. Tree derived from Bayesian analysis of combined $12 \mathrm{~S}$ and $16 \mathrm{~S}$ rDNA fragments. Average posterior probabilities are shown above nodes. The tree was rooted using Mabuya maculilabris and Chalcides chalcides. The tree derived from ML analysis, obtained with PAUP and with a model of sequence evolution GTR $+\mathrm{I}+\mathrm{G}$ (described in the text), shows a similar pattern, except for being less well resolved and few differences in terminal branches on small groups (bootstrap values are shown below the nodes, but only for the major groups). 


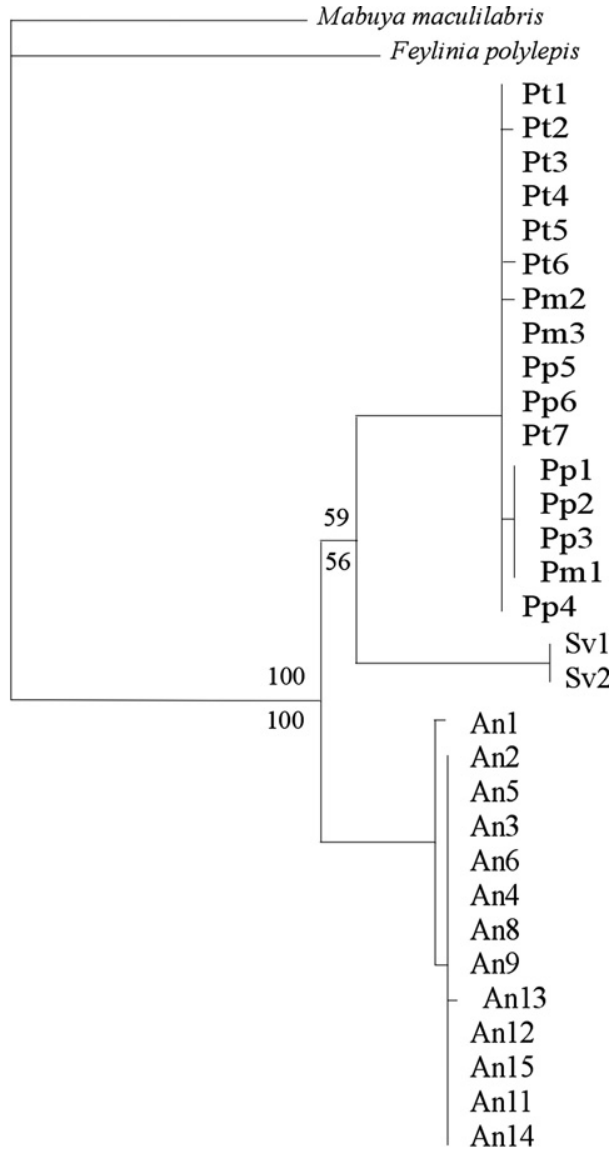

0.1 expected changes per site

Fig. 3. Tree derived from Bayesian analysis of combined 12S rDNA, 16S rDNA fragments and cytochrome $b$. Average posterior probabilities are shown above nodes. The tree was rooted using Mabuya maculilabris and Feylinia polylepis. The tree derived from ML analysis, obtained with PAUP and with a model of sequence evolution GTR $+\mathrm{I}+\mathrm{G}$ (described in the text), shows a similar pattern. Bootstrap values are shown below the nodes, but only for the major groups.

that there is a rapid molecular divergence caused by a founding event. So, taking into account the greater branch lengths and longer distances of Annobon to the continent,
Table 3

Descriptive statistics of cytochrome $b \mathrm{~K} 2 \mathrm{P}$ pairwise distances among and between islands of Afroablepharus haplotypes used in this study

\begin{tabular}{llll}
\hline & Príncipe & São Tomé & Annobon \\
\hline Príncipe & $0.00788 \pm 0.00609$ & $0.23431 \pm 0.00383$ & $0.21562 \pm 0.00452$ \\
& {$[0.022 ; 0]$} & {$[0.245 ; 0.231]$} & {$[0.223 ; 0.203]$} \\
São Tomé & & 0.005 & $0.21831 \pm 0.00213$ \\
& & & {$[0.222 ; 0.216]$} \\
Annobon & & & $0.00345 \pm 0.00272$ \\
& & & {$[0.009 ; 0]$} \\
\hline
\end{tabular}

In each cell, the upper line gives mean \pm standard deviation; the lower line gives the maximum and minimum.

the most parsimonious scenario seems to be that the first island that was colonized was São Tomé, followed by spreading to other islands.

Given the high intraspecific diversity recorded in these islands, more sampling in sub-Saharan Africa is clearly necessary. Indeed, it would be interesting to investigate the genetic diversity of Afroablepharus, particularly $A$. wahlbergi, throughout its range. Phylogeographic structuring of $A$. wahlbergi populations may provide some further indication of the most likely geographic origin of the Gulf of Guinea island taxa.

The colonization pattern of Afroablepharus does not seem to be similar to other reptiles from these islands. Mabuya spp. on the islands do not form a clade, suggesting separate colonization of each island from the mainland (Jesus et al., 2005c). Endemic island geckos of the genus Hemidactylus also do not form a monophyletic group and probably colonized the islands from the mainland more than once (Jesus et al., 2005a).

Considering the molecular clock in other reptiles of about $2 \%$ divergence per Myr for cytochrome $b$ on the lacertid lizard Gallotia (Carranza et al., 2000), 2.2\% for other lacertid lizards (Maca-Meyer et al., 2003), or even 2.6\% per million years in Tarentola (Carranza et al., 2002), it is extremely difficult to explain these results. Using the value of $2 \%$, the forms from the three islands split about $10 \mathrm{Myr}$ ago, which is difficult to reconcile with the age of Annobon (4.5 Myr). Either the molecular clock rate does not apply

Table 2

Cytochrome $b \mathrm{~K} 2 \mathrm{P}$ pairwise distances for the island Afroablepharus haplotypes used in this study

\begin{tabular}{|c|c|c|c|c|c|c|c|c|c|c|c|c|}
\hline & Pt1 & Pt6 & $\mathrm{Pt} 7$ & Pp5 & Pp6 & Pm1 & $\mathrm{Pm} 2$ & Pm3 & Sv1 & Sv2 & An1 & An2 \\
\hline Pt6 & 0.005 & & & & & & & & & & & \\
\hline Pt7 & 0.000 & 0.005 & & & & & & & & & & \\
\hline Pp5 & 0.002 & 0.007 & 0.002 & & & & & & & & & \\
\hline Pm1 & 0.017 & 0.022 & 0.017 & 0.019 & 0.017 & & & & & & & \\
\hline $\operatorname{Pm} 2$ & 0.002 & 0.002 & 0.002 & 0.005 & 0.002 & 0.019 & & & & & & \\
\hline Pm3 & 0.000 & 0.005 & 0.000 & 0.002 & 0.000 & 0.017 & 0.002 & & & & & \\
\hline An1 & 0.207 & 0.213 & 0.207 & 0.203 & 0.207 & 0.213 & 0.210 & 0.207 & 0.222 & 0.222 & & \\
\hline An2 & 0.213 & 0.220 & 0.213 & 0.210 & 0.213 & 0.220 & 0.216 & 0.213 & 0.219 & 0.219 & 0.007 & \\
\hline An3 & 0.213 & 0.220 & 0.213 & 0.210 & 0.213 & 0.220 & 0.216 & 0.213 & 0.219 & 0.219 & 0.009 & 0.002 \\
\hline
\end{tabular}

Coding/abbreviations are as follows: An. Annobon, Pt. Príncipe-Terreiro Velho, Pm. Príncipe-Montalegre, Pp. Príncipe-Ponta do Sol, Sv. São Tomé-Vale do Contador. Following the two letters are numbers that identify the samples or each individual. 

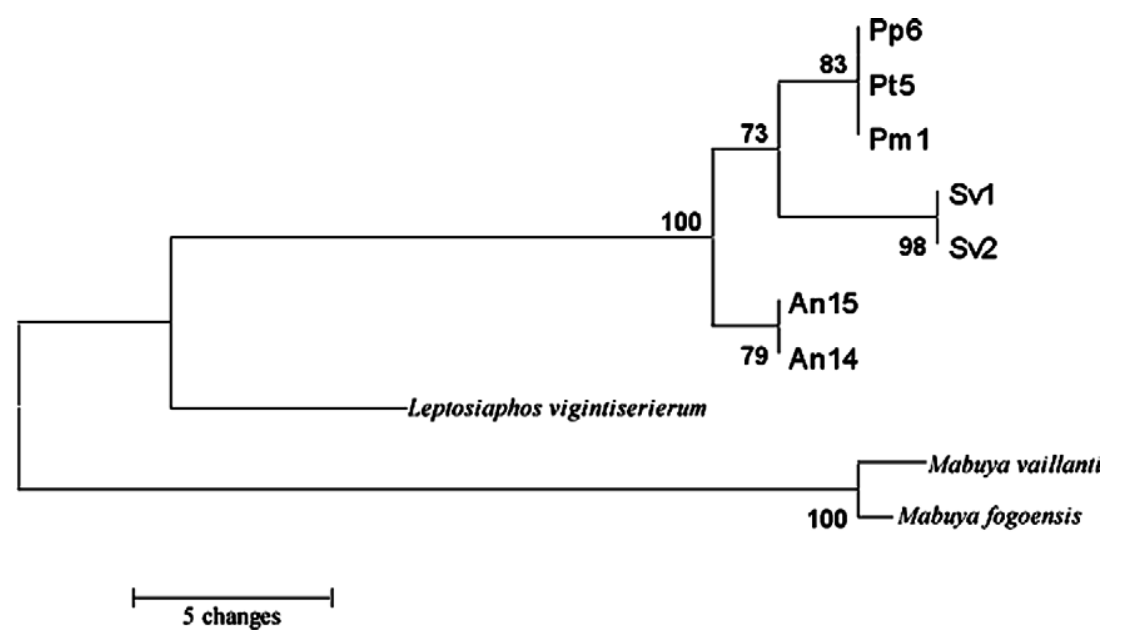

Fig. 4. MP tree obtained with Close-Neighbor-Interchange (CNI) with search level 3, showing the relationships derived from partial sequences of $c-m o s$. As all individuals within an island shared the same haplotype, not all are indicated. Coding/abbreviations areas follows: An. Annobon, Pt. PríncipeTerreiro Velho, Pm. Príncipe-Montalegre, Pp. Príncipe-Ponta do Sol, Sv. São Tomé-Vale do Contador. Following the two letters are numbers that identify the samples or each individual. Bootstrap values are shown above the nodes (see text for more details).

to the Panaspis skinks of Gulf of Guinea populations, or the geological dating of the emergence of the islands is erroneous. If the molecular clock is well calibrated, a possible explanation is that the lineage of Annobon originated elsewhere but currently exists only in Annobon. Following this reasoning, the forms in Gulf of Guinea would eventually have different mainland ancestors either unsampled or even extinct. It is almost impossible to sample all probable origin areas, because they are extensive and because some species could be geographically restricted and, as in Gulf of Guinea, living among leafliter, are difficult to discover. However, this seems unlikely since it would imply the form evolved on one of the other Gulf of Guinea islands in sympatry with another lineage of Afroablepharus. Such scenarios rarely occur on small islands where minimal separation into different ecological niches is possible. Further all Afroablepharus currently found on the islands occupy the same niche, being found in leaf litter in the forests, and are very similar morphologically. It seems more likely that the currently used calibration is unreliable across different taxa. This has also been reported from Anolis extremus of Barbados islands (Thorpe et al., 2005), and clearly deserves further investigation.

\subsection{Taxonomic status of the Gulf of Guinea species}

Except for São Tomé where only two individuals were studied, the genetic diversity within each island is very low (Table 2 and Fig. 2), probably due to the small population size on islands, to bottlenecks from colonization, or to a strong directional selection. In fact these skinks were found in leaf litter only in moist and shady places, under trees (Jesus et al., 2003; pers. obs).

Our results group Gulf of Guinea populations with Afroablepharus wahlbergi (see Fig. 2). So, despite lacking typical morphological features of Afroablepharus, the forms from Gulf of Guinea must be considered as Afroab- lepharus. One hypothesis to be tested in the future is that the typical morphological characters used at generic level are homoplastic.

The values for divergence between islands based on cytochrome $b$, are extremely high for intraspecific variation. Values of $20-23 \%$ of divergence observed between the three islands are much higher than the average value obtained for other reptiles (Harris, 2002). Also in c-mos we found a higher number of differences (5-7) between the forms of Gulf of Guinea than between other recognized species such as Mabuya vaillanti and Mabuya fogoensis (Brehm et al., 2001).

We recognize three different species. Morphological differences between the forms of Príncipe and São Tomé are pratically absent, and this was, probably, the reason why the original description made by Gray, 1845 of $A$. africanus was apparently based on lizards from Príncipe and São Tomé. Unfortunately the type locality is given only as "West Africa". We suggest that the form from Príncipe should retain the name A. africanus and the Terra typica should be restricted to Príncipe. The form from São Tomé should be considered a new species, pending ongoing morphological analyses. The process of description of the form of São Tomé is almost done.

Although similar in general morphology the form from Annobon presents some morphological differences, namely higher number of subdigital lamellae in the forth toe of the hind and fore limbs, relatively longer limbs, broader loreal and darker colour (Fuhn, 1972; Perret, 1973). These differences were sufficient to consider the form of Annobon a different subspecies, A. africanus annobonensis (Fuhn, 1972) or even to be suggested as different species (Perret, 1973). The statement of Perret, 1973 is enhanced by our results. The morphological differences, and the high genetic divergence in relation to other forms of Gulf of Guinea, obtained in this study, should be sufficient to consider the form of Annobon a different species, A. annobonensis. 


\section{Acknowledgments}

This project was supported by grants from Fundação para a Ciência e Tecnologia POCTI/41906/BSE/2001 and SFRH/BDP/5702/2001. Fieldwork was also supported by the Instituto Gulbenkian de Ciência (to D.J.H).

We would like to thank the Government of São Tomé and Príncipe and the Representative of Equatorial Guinea in São Tomé for the permissions to perform the field work.

We would like to thank Andreas Schmitz for providing some data, samples and sequences of Panaspis (sensu lato), and Robert Drewes for providing some important references.

We also thank the anonymous referees for their comments.

\section{References}

Boulenger, G.A., 1887. Catalogue of the lizards in the British Museum (Natural History).

Brehm, A., Jesus, J., Pinheiro, M., Harris, D.J., 2001. Relationships of scincid lizards (Mabuya spp.; Reptilia: Scincidae) from Cape Verde islands based on mitochondrial and nuclear DNA sequences. Mol. Phylogenet. Evol. 19, 311-416.

Burke, K., 2001. Origin of the Cameroon line of volcano-capped swells. J. Geol. 109, 349-362.

Carranza, S., Arnold, E.N., Mateo, J.A., Lopez-Jurado, L.F., 2000. Longdistance colonization and radiation in gekkonid lizards, Tarentola (Reptilia: Gekkonidae) revealed by mitochondrial DNA sequences. Proc. R. Soc. Lond. B 267, 637-649.

Carranza, S., Arnold, E.N., Mateo, J.A., Geniez, P., 2002. Relationships and evolution of the North African geckos Geckonia and Tarentola, based on mitochondrial and nuclear DNA sequences. Mol. Phylogenet. Evol. 23, 244-256.

Cope, E.D., 1868. Observations on reptiles of the Old World, II. Proc. Acad. Nat. Sci. Phila. 1868, 316-323.

Emerson, B.C., 2002. Evolution on oceanic islands: molecular phylogenetic approaches to understanding pattern and process. Mol. Ecol. 11, 951-966.

Farris, J.S., Källersjö, M., Kluge, A.G., Bult, C., 1994. Testing significance of congruence. Cladistics 10, 315-319.

Felsenstein, J., 1985. Confidence limits on phylogenies: an approach using the bootstrap. Evolution 39, 783-791.

Fuhn, I.E., 1969. Revision and redefinition of the genus Ablepharus Lichtenstein, 1823 (Reptilia, Scincidae). Revue roum. Biol. Zool. 14, 23-41.

Fuhn, I.E., 1972. Révision du phylum forestier du genre Panaspis Cope (Reptilia, Scincidae, Lygosominae). Revue roum. Biol. Zool. 17, $257-$ 271.

Gray, I.E., 1845. Catalogue of the specimens of lizards in the collection of the British Museum, London.

Greer, A.E., 1974. The generic relationships of the scincid lizard genus Leiolopisma and its relatives. Aust. J. Zool., Suppl. Ser. 31, 1-67.

Harris, D.J., 2002. Reassessment of comparative genetic distance in reptiles from the mitochondrial cytochrome $b$ gene. Herp. J. 12, 85-86.

Ho, S.Y.W., Phillips, M.J., Drummond, A.J., Cooper, A., 2005. Accuracy of rate estimation using relaxed-clock models with a critical focus on the early metazoan radiation. Mol. Biol. Evol. 22, 1355-1363.

Huelsenbeck, J.P., Crandall, K.A., 1997. Phylogeny estimation and hypothesis testing using maximum likelihood. Ann. Rev. Ecol. Syst. 28, 437-466.

Huelsenbeck, J.P., Ronquist, F., 2001. MR-BAYES: Bayesian inference of phylogeny. Bioinformatics 17, 754-755.

Jesus, J., Brehm, A., Harris, D.J., 2003. The herpetofauna of Annobon island, Gulf of Guinea, West Africa. Br. Herp. Soc. Bull. 86, 20-22.
Jesus, J., Brehm, A., Harris, D.J., 2005a. Phylogenetic relationships of Hemidactylus geckos from the Gulf of Guinea islands: patterns of natural colonizations and anthropogenic introductions estimated from mitochondrial and nuclear DNA sequences. Mol. Phylogenet. Evol. $37,480-485$.

Jesus, J., Harris, D.J., Brehm, A., 2005b. Phylogeography of Mabuya maculilabris (Reptilia) from São Tomé Island (Gulf of Guinea) inferred from mtDNA sequences. Mol. Phylogenet. Evol. 37, 503-510.

Jesus, J., Brehm, A., Harris, D.J., 2005c. Relationships of scincid lizards (Mabuya spp.) from the islands of the Gulf of Guinea based on mtDNA sequence data. Amphibia-Reptilia 26, 467-473.

Jesus, J., Brehm, A., Harris, D.J., 2006. Phylogenetic relationships of Lygodactylus geckos from the Gulf of Guinea islands: rapid rates of mitochondrial DNA sequence evolution?. Herpetol. J. 16 291-295.

Kocher, T.D., Thomas, W.K., Meyer, A., Edwards, S.V., Pääbo, S., Villablanca, F.X., Wilson, A.C., 1989. Dynamics of mitochondrial DNA evolution in animals: amplification and sequencing with conserved primers. Proc. Natl. Acad. Sci. USA 86, 6196-6200.

Kumar, S., Tamura, K., Nei, M., 2004. MEGA3: integrated software for molecular evolutionary genetics analysis and sequence alignment. Brief. Bioinform. 5, 150-163.

Lee, D.C., Halliday, J.G., Fitton, J.G., Poli, G., 1994. Isotopic variations with distances and time in the volcanic islands of the Cameroon line: evidence for mantle plume origin. Earth Planet. Sci. Lett. 123, 119139.

Maca-Meyer, N., Carranza, S., Rando, J., Arnold, E., Cabrera, V., 2003. Status and relationships of the extinct giant canary island lizard Gallotia galloti (Reptilia: lacertidae) assessed using ancient mtDNA from its mummified remains. Biol. J. Linn. Soc. 80, 659-670.

Measey, G.J., Vences, M., Drewes, R.C., Chiari, Y., Melo, M., Bourles, B., 2007. Freshwater paths across the ocean: molecular phylogeny of the frog Ptychadena newtoni gives insights into amphibian colonization of oceanic islands. J. Biogeogr. 34, 7-20.

Meyers, J., Rosendahl, B., Harrison, C., Ding, Z., 1998. Deep-imaging seismic and gravity results from offshore Cameroon Volcanic Line, and speculation of African hotlines. Tectonophysics 284, 31-63.

Mittleman, M.B., 1952. A generic synopsis of the lizards of the subfamily Lygosominae. Smithson. Misc. Collect. 117, 1-35.

Myers, N., Mittmeier, R.A., Mittmeier, C.G., Da Fonseca, G.A., Kent, J., 2000. Biodiversity hotsposts for conservation priorities. Nature 403, 853-858.

Palumbi, S., Martin, A., Romano, S., McMillan, W., Stick, L., Grabowski, G., 1991. The single tools guide to PCRMarine Version 2. Honolulu, Hawaii.

Perret, J.-L., 1973. Contribution à l'étude des Panaspis (Reptilia, Scincidae) d'Afrique occidentale avec la description de deux espèces nouvelles. Rev. Suisse Zool. 80, 595-630.

Perret, J.-L., 1975. La différenciation dans le genre Panapis Cope (Reptilia, Scincidae). Bull. Soc. neuch. Sci. Nat. 98, 5-16.

Posada, D., Crandall, K.A., 1998. Modeltest: testing the model of DNA substitution. Bioinformatics 14, 817-818.

Posada, D., Buckley, T.R., 2004. Model selection and model averaging in phylogenetics: advantages of the AIC and Bayesian approaches over likelihood ratio tests. Syst. Biol. 53, 793-808.

Rambaut, A., Drummond, A., 2005. Tracer. A program for analysing results from Bayesian MCMC programs such as BEAST \& MrBayes. Version 1.3. <http://evolve.zoo.ox.ac.uk/software.html?id=tracer>

Rodríguez, F., Oliver, J.F., Marín, A., Medina, J.R., 1990. The generar stochastic model of nucleotide substitutions. J. Theor. Biol. 142, 485-501.

Saint, K.M., Austin, C.C., Donnellan, S.C., Hutchinson, M.N., 1998. Cmos, a nuclear marker useful for squamate phylogenetic analysis. Mol. Phylogenet. Evol. 10, 259-263.

Sambrook, J., Fritsch, E.F., Maniatis, T., 1989. Molecular Cloning: A Laboratory Manual, third ed. Cold Spring Harbour Press, New York.

Schmitz, A., Ineich, I., Chirio, L., 2005. Molecular review of the genus Panaspis sensu lato (Reptilia: Scincidae) in Cameroon, with special reference to the status of the proposed subgenera. Zootaxa 863, $1-28$ 
Simkin, T., Siebert, L., 1994. Volcanoes of the World. Geoscience Press, Tucson, Arizona.

Simon, C., Franke, A., Martin, A., 1990. The polymerase chain reaction: DNA extraction and amplification. In: Hewitt, G., Johnston, A., Young, Y. (Eds.), Molecular techniques in taxonomy. NATO ASI Series, vol. H57. Springer Verlag, Berlin, pp. 329-357.

Smith, M.A., 1937. A review of the genus Lygosoma (Scincidae: Reptilia) and its allies. Rec. Indian Mus. 39, 213-234.

Swofford, D.L., 2002. PAUP*: Phylogenetic Analysis Using Parsimony (and other methods) 4.0.b10. Sinauer Associates Sunderland, Massachusetts, USA.

Swofford, D.L., Olsen, G.J., Waddell, P.J., Hillis, D.M., 1996. Phylogenetic inference. In: Hillis, D.M., Moritz, C., Mable, B.K. (Eds.), Mol. Syst., second ed. Sinauer Associates, Sunderland, MA.
Thompson, J.D., Higgins, D.G., Gibson, T.J., 1994. Clustal W: improving the sensitivity of progressive multiple sequence alignment through sequence weighting, position specific gap penalties and weight matrix choice. Nucleic Acids Res. 22, 4673-4680.

Thorpe, R.S., Leadbeater, D.L., Pook, C.E., 2005. Molecular clocks and geological dates: cytochrome $b$ of Anolis extremus substantially contradicts dating of Barbados emergence. Mol. Ecol. 14, 20872096.

Xia, X., Xie, Z., 2001. DAMBE: data analysis in molecular biology and evolution. J. Hered. 92, 371-373.

Welch, K.G., 1982. Herpetology of Africa: a checklist and bibliography of the orders Amphisbaenia, Sauria and Serpentes. Robert E. Krieger Publishing Company Malaber, Florida. 